\title{
Penilaian Kuantitatif Risiko Wisata di Kawasan Wisata Pantai Pangandaran
}

\author{
Raihan Dikara $^{1 *}$, Ankiq Taofiqurohman', Iskandar ${ }^{2}$ \\ ${ }^{I}$ Departemen Ilmu Kelautan, Fakultas Perikanan dan Ilmu Kelautan, Universitas Padjadjaran \\ ${ }^{2}$ Departemen Perikanan, Fakultas Perikanan dan Ilmu Kelautan, Universitas Padjadjaran \\ Jl. Raya Bandung-Sumedang KM 21, Jatinangor, Sumedang 45363, Jawa Barat \\ Email: raihandkr@gmail.com
}

\begin{abstract}
Abstrak
Pantai Pangandaran merupakan salah satu objek wisata pesisir yang terletak di Kabupaten Pangandaran, Provinsi Jawa Barat dan merupakan salah satu obyek wisata unggulan di Provinsi Jawa Barat. Tetapi wisata di Pantai Pangandaran memiliki potensi bahaya fisik dan dalam beberapa kasus menimbulkan korban jiwa. Riset ini bertujuan untuk mengidentifikasi potensi bahaya fisik pantai bagi keselamatan pengunjung, menilai tingkatan risiko dari potensi bahaya fisik pantai bagi keselamatan pengunjung, dan menentukan penyebab tingginya risiko wisata di Kawasan Wisata Pantai Pangandaran. Metode yang digunakan riset ini adalah metode assessment. Data yang digunakan pada assessment tingkat risiko pantai yaitu: jumlah pengunjung, jumlah lifeguard, panjang pantai, jumlah rambu, penggunaan lifejacket, kecelakaan wisatawan, tipe pantai, dan tinggi gelombang. Hasil riset menunjukkan Kawasan Wisata Pantai Pangandaran termasuk kedalam tipe pantai longshore bar and trough. Kawasan Wisata Pantai Pangandaran termasuk kedalam kategori multiple fatalities dengan nilai R (tingkat risiko) lebih dari 200 di semua pantai pada periode low season ataupun high season. Khusus Pantai Barat pada periode high season kategori menurun menjadi fatal. Terdapat perbedaan nilai $\mathrm{R}$ yang signifikan pada kedua periode. Perbedaan nilai $\mathrm{R}$ menunjukan Kawasan Wisata Pantai Pangandaran relatif lebih aman pada periode high season. Penyebab utama dari tingginya tingkat risiko wisata di Kawasan Wisata Pantai Pangandaran adalah jumlah personil lifeguard dan rambu-rambu peringatan yang tidak mencukupi.
\end{abstract}

Kata kunci : Keselamatan, Risiko wisata pantai, Wisata, Pantai Pangandaran

\section{Abstract \\ Quantitive Risk Assessment of Tourism in Pangandaran Beach Tourism Area}

Pangandaran Beach is one of the coastal tourism objects located in Pangandaran Regency, West Java Province and it is one of the leading tourism object in West Java Province. Tourism in Pangandaran has beach-physical potential hazard and some case of it creating casualties. This research aims to identify the potential physical hazards of the beach for the safety of visitors, assess the risk level of beach-physical potential hazard for the safety of visitors, and determine the cause of the high number of tourism risk in the Pangandaran Beach Tourism Area. The method used in this research is the assessment method. The data used in the assessment of the level of beach risk are: number of visitors, number of lifeguards, beach length, number of signages, lifejacket usage, tourist accident, beach type, and wave height. Research results show that Pangandaran Beach Tourism Area belonged to longshore bar and trough beach type. Pangandaran Beach Tourism Area is belonged to multiple fatalities category with an $R$ value (risk level) more than 200 on all beaches either on low season or high season. At high season period on West Beach the category shift to fatal. There is a significant difference in $R$ value between two periods. The difference in value of $R$ shows that Pangandaran Beach Tourism Area is relatively safer during the high season period. The main cause of the high number of tourism risk in the Pangandaran Beach Tourism Area are the insufficient number of lifeguard and warning signs.

Keywords : Safety, Beach tourism risk, Tourism, Pangandaran Beach 


\section{PENDAHULUAN}

Pantai Pangandaran merupakan salah satu objek wisata pesisir di Kabupaten Pangandaran, Provinsi Jawa Barat. Pantai Pangandaran menjadi objek wisata pantai andalan di Jawa Barat. Menurut Dinas Pariwisata dan Kebudayaan Kabupaten Pangandaran (2019) pada tahun 2017 Pantai Pangandaran dikunjungi oleh 2.061.547 wisatawan, pada tahun 2018 dikunjungi oleh 2.789.905, dan pada tahun 2019 dikunjungi oleh 2.665.211 wisatawan.

Kawasan Wisata Pantai Pangandaran memikat wisatawan dengan keindahannya. Namun wisata pantai memiliki risiko kecelakaan relatif tinggi dibandingkan aktifitas wisata di daratan (Taofiqurohman et al., 2020). Hal tersebut dibuktikan dengan jumlah kecelakaan yang dicatat oleh Balai Wisata Tirta (Balawista). Pada tahun 2016 terjadi 116 kecelakaan, pada tahun 2017 terjadi 176 kecelakaan, dan pada tahun 2018 terjadi 47 kecelakaan. Menurut Balawista wisatawan tenggelam mendominasi kecelakaan yang terjadi di Kawasan Wisata Pantai Pangandaran. Umumnya kecalakaan wisata disebabkan oleh faktor oseanografi yang ada di Pantai Pangandaran. Faktor lainnya yang turut berperan dalam kecelakaan di pantai yaitu masih kurangnya pemahaman masyarakat mengenai bahaya pantai serta masyarakat belum memahami sepenuhnya makna dari rambu-rambu peringatan yang terdapat di sekitar Pantai Pangandaran.

Keselamatan merupakan faktor utama yang menjadi pertimbangan wisatawan untuk memutuskan memilih destinasi wisata yang akan dikunjungi (Hermawan, 2017). Upaya meningkatkan keselamatan wisatawan dapat dilakukan dengan mengevaluasi setiap risiko bahaya melalui manajemen bahaya yang meliputi penerimaan atas kejadian yang dapat ditoleransi, meminimalisir risiko, dan mengalihkan risiko (Achjar. 2020).

Kunci sukses sebuah kegiatan pariwisata harus memperhatikan kenyamanan dan keamanan (Kusuma dan Suryawan, 2016). Maka dari itu pengelolaan risiko wisata merupakan hal yang penting dalam menjamin keselamatan wisatawan. Faktor fisik yang dapat membahayakan keselamatan wisata, bagaimana tingkatan bahaya tersebut, serta apa saja penyebab tingginya risiko wisata di kawasan Pantai Pangandaran perlu diketahui untuk mempermudah pengelolaan risiko. Jika faktor bahaya dapat diidentifikasi maka hal tersebut diharapkan dapat menjadi acuan bagi pengelola wisata dan pemerintah daerah untuk meningkatkan infrastruktur penunjang keselamatan serta menurunkan jumlah kecelakaan di kawasan Pantai Pangandaran.

\section{MATERI DAN METODE}

Riset ini telah dilaksanakan pada bulan Oktober 2019 - Februari 2020 yang terdiri dari beberapa tahap yaitu, tahap survei, tahap pengambilan data, dan pengolahan data. Riset ini dilakukan di Kawasan Wisata Pantai Pangandaran, Kabupaten Pangandaran, Jawa Barat. Untuk wilayah pantai yang akan digunakan sebagai tempat pengambilan data meliputi Pantai Timur Pangandaran, Pantai Barat Pangandaran, dan Pantai Pananjung (Gambar 1). Wilayah yang dipilih merupakan bagian pantai yang biasa digunakan untuk aktivitas wisata oleh wisatawan.

Metode yang digunakan dalam riset ini adalah metode assessment. Dalam ruang lingkup keselamtan wisata pantai, assement dapat didefinisikan sebagai proses quantifikasi dampak bahaya dari individu, kelompok, peralatan, atau lingkungan dari interaksi manusia dan manajemen keselamatan dalam lingkungan perairan (Chris,2014). Data yang digunakan pada riset ini terbagi dua yaitu data primer dan data sekunder. Data primer meliputi data jumlah lifeguard, data jumlah rambu peringatan, data penggunaan lifejacket, dan data panjang pantai. sedangkan data sekunder meliputi data jumlah pengunjung yang diperoleh dari Disparbud Kab. Pangandaran tahun 22019 , data tipe pantai yang diperoleh dari riset Kusmanto dan Setiawan (2011), dan data tinggi rata-rata gelombang yang diperoleh dari riset Taofiqurohman et al. (2020).

Untuk menjamin keselamatan wisata pantai diperlukan sebuah assessment untuk menetukan faktor risiko yang terdapat di kawasan pantai. Assessment tersebut meliputi karakteristik pantai, jumlah pengunjung, faktor penyelamatan darurat, faktor pencegahan risiko, dan faktor kesiapan keselamatan. Program assessment risiko yang dilaksanakan dengan baik dapat membantu dalam pencegahan kecelakaan tenggelam dan cedera saat berenang. Program tersebut dapat memperbaiki jumlah minimum penjaga pantai, membantu mengefektifkan manajemen pantai yang akan menguntungkan bagi pengelola pantai, penjaga pantai dan pihak lainnya yang terkait (ILSE 2005).

Data-data tersebut kemudian diolah dengan rumus yang digunakan pada riset Yang et al. (2014) untuk menghasilkan data tingkat risiko 
pantai. Rumus yang digunakan adalah sebagai berikut:

$$
\mathrm{R}=\mathrm{S} \times \mathrm{N} \times[(1-\mathrm{E}) \times(1-\mathrm{W}) \times(1-\mathrm{P}) \times \mathrm{H}]
$$

Keterangan: $\mathrm{R}=$ Tingkat risiko; $\mathrm{S}=$ Tingkat bahaya pantai; $\mathrm{N}=$ Jumlah pengunjung harian; $\mathrm{E}=$ Faktor penyelamatan darurat; $\mathrm{W}=$ Faktor pencegahan risiko; $\mathrm{P}=$ Faktor kesiapan keselamatan; $\mathrm{H}$ = Tinggi rata-rata gelombang

\section{Tingkat Bahaya Pantai}

Tingkat bahaya pantai dapat ditentukan berdasarkan tipe pantai. Riset Short (2006) mengemukakan tipe-tipe pantai terklasifikasi kedalam tiga bagian berdasarkan faktor gelombang yang dominan terjadi di pantai tersebut yaitu, wave-dominated beach, tide-modified beach, dan tide-dominated beach. Klasifikasi pantai tersebut terdiri dari beberapa tipe pantai yang digolongkan berdasarkan morfologi dan karakteristik pantainya. Tipe pantai yang sudah ditentukan kemudian dicocokan berdasarkan morfologi dan karakteristik pantai kedalam panduan tingkat bahaya pantai pada Tabel 1 sebagai berikut. Kemudian nilai yang diperoleh menjadi variabel $\mathrm{S}$ dalam rumus perhitungan tingkat risiko pantai.

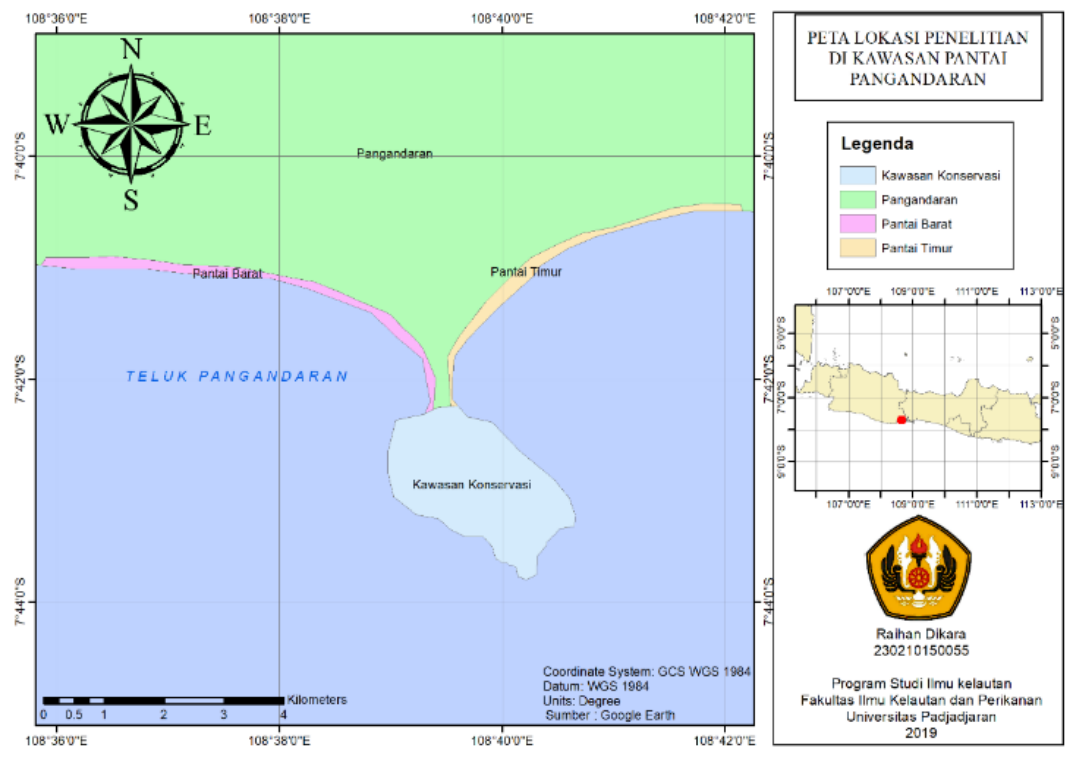

Gambar 1. Peta Lokasi Riset

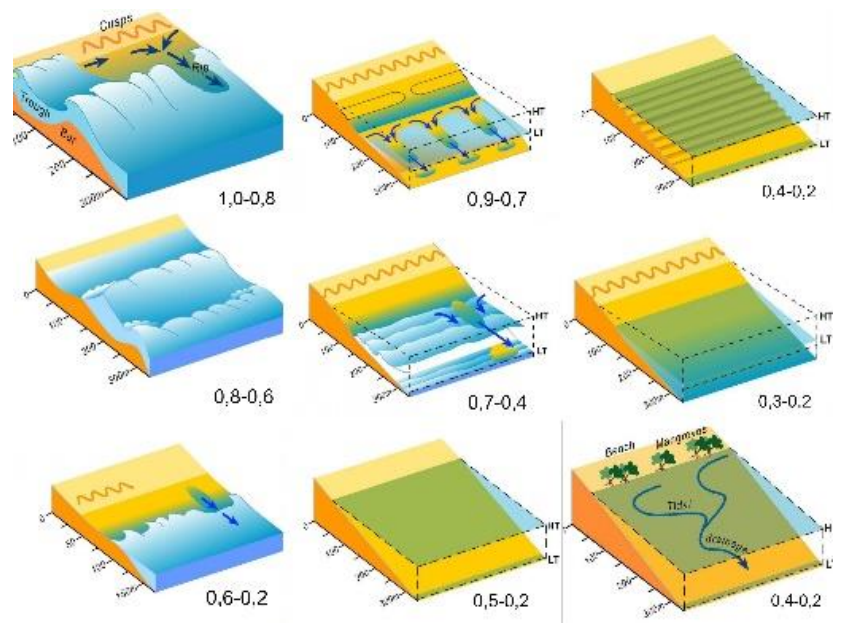

Gambar 2. Tipe Pantai

Sumber: Yang et al., 2014 
Tabel 1. Panduan Tingkat Bahaya Pantai

\begin{tabular}{|c|c|c|}
\hline Tipe Pantai & $\begin{array}{l}\text { Tingkat } \\
\text { Bahaya }\end{array}$ & Karakteristik \\
\hline Longshore bar and trough & $1,0-0,8$ & $\begin{array}{c}\text { Wave dominated: tinggi gelombang lebih dari } 1,5 \mathrm{~m} \text {, bentuk } \\
\text { sandbar lurus dan seragam disepanjang pesisir, energi gelombang } \\
\text { tinggi. }\end{array}$ \\
\hline Dissipative & $0,8-0,6$ & $\begin{array}{l}\text { Wave dominated: tinggi gelombang } 0,5-1,5 \mathrm{~m} \text {, bentuk sandbar } \\
\text { lurus dan seragam disepanjang pesisir, energi gelombang sedang. }\end{array}$ \\
\hline Low tide Terrace & $0,6-0,2$ & $\begin{array}{l}\text { Wave dominated: tinggi gelombang kurang dari } 0,5 \mathrm{~m} \text {, pantai } \\
\text { berbentuk cekungan, energi gelombang rendah. }\end{array}$ \\
\hline Reflective + bars & $0,9-0,7$ & $\begin{array}{c}\text { Wave-tide modified: tinggi gelombang lebih dari } 1,0 \mathrm{~m} \text {, bentuk } \\
\text { sandbar lurus dan seragam disepanjang pesisir, energi gelombang } \\
\text { tinggi. }\end{array}$ \\
\hline $\begin{array}{l}\text { Reflective }+ \text { low tide } \\
\text { terrace }\end{array}$ & $0,7-0,4$ & $\begin{array}{l}\text { Wave-tide modified: tinggi gelombang berkisar } 0,5-1,0 \mathrm{~m} \text {, bentuk } \\
\text { sandbar lurus dan seragam disepanjang pesisir, energi gelombang } \\
\text { sedang. }\end{array}$ \\
\hline Ultradissipative & $0,5-0,2$ & $\begin{array}{c}\text { Wave-tide modified: tinggi gelombang kurang dari } 0,5 \mathrm{~m} \text {, bentuk } \\
\text { sandbar lurus dan seragam disepanjang pesisir, energi gelombang } \\
\text { rendah. }\end{array}$ \\
\hline $\begin{array}{l}\text { Reflective }+ \text { ridged sand } \\
\text { flat }\end{array}$ & $0,5-0,3$ & $\begin{array}{c}\text { Tide-dominated: tinggi gelombang lebih dari } 1,0 \mathrm{~m} \text {, pantai } \\
\text { berbentuk cekungan, energi gelombang tinggi. }\end{array}$ \\
\hline Reflective + Sand flat & $0,3-0,2$ & $\begin{array}{l}\text { Tide-dominated: tinggi gelombang berkisar } 0,5-1,0 \mathrm{~m} \text {, pantai } \\
\text { berbentuk cekungan, energi gelombang sedang }\end{array}$ \\
\hline Reflective + tidal mud flat & $0,4-0,2$ & $\begin{array}{c}\text { Tide-dominated: tinggi gelombang kurang dari } 0.5 \mathrm{~m} \text {, pantai } \\
\text { berbentuk cekungan }\end{array}$ \\
\hline
\end{tabular}

Sumber: Yang et al., 2014

\section{Faktor Penyelamatan Darurat}

Faktor Penyelamatan darurat (E) merupakan kemampuan penyelamatan antara penjaga pantai dan kecelakaan di surf zone. Ketika kecelakaan memerlukan operasi penyelamatan yang terjadi di dalam zona berenang, E merupakan faktor yang menentukan apakah penjaga pantai dapat menolong dan wisatawan dapat diselamatkan sebelum tenggelam. Hal tersebut dapat mempengaruh seberapa cepat penjaga pantai dapat menolong korban. Oleh karena itu, jumlah penjaga pantai yang tidak mencukupi dapat menyebabkan kecelakaan fatal. Faktor penyelamatan darurat ditentukan nilainya berdasarkan jumlah penjaga pantai dalam satuan panjang dari pantai yang biasa digunakan untuk aktivitas wisata kemudian dikalikan $10^{-3}$ seperti pada rumus berikut:

$(1-E)=($ jumlah penjaga pantai $\div$ panjang pantai $) \times 10^{\wedge-3}$

\section{Faktor Pencegahan Risiko}

Faktor pencegahan risiko (W) memiliki makna sebagai dampak terhadap bahaya yang dihadapi oleh pengunjung pantai. Jumlah dari fasilitas keselamatan yang terpasang, seperti rambu, papan informasi bahaya, dan peringatan bahaya, dianggap sebagai bahaya yang dapat dicegah karena disebabkan oleh persepsi bahaya (Michael et al., 2007). Jika para pengunjung tidak menyadari akan bahaya maka peningkatan risiko kecelakaan dari bahaya dapat terjadi kepada sebagian besar pengunjung pantai. Nilai dari faktor pencegahan risiko ditentukan dengan perhitungan yang sama seperti faktor penyelamatan darurat dengan rumus sebagai berikut:

$$
(1-\mathrm{W})=(\text { jumlah rambu } \div \text { panjang pantai }) \times 10^{\wedge-3}
$$

\section{Faktor Kesiapan Keselamatan}

Faktor kesiapan keselamatan (P) diasosiasikan dengan mencegah kecelakaan seperti penggunaan lifejacket. Jika pengelola pantai menyediakan dan mengharuskan pengunjung menggunakan lifejacket, maka diberikan nilai 0,1 . Jika manajemen tidak menyediakan lifejacket namun mengharuskan pengunjung menggunakan alat pelampung pribadi, maka diberikan nilai 0,5. Namun jika pengelola pantai tidak menyediakan 
dan tidak mengharuskan pengunjung menggunakan lifejacket, maka hal tersebut dianggap sebagai perilaku yang berkontribusi dalam faktor penyebab kecelakaan karena tenggelam, sehingga diberikan nilai 1,0.

\section{HASIL DAN PEMBAHASAN}

Kawasan Wisata Pantai Pangandaran terbagi dalam tiga bagian, yaitu Pantai Barat, Pantai Timur, dan Pantai Pananjung. Ketiga pantai tersebut memiliki karakteristik tersendiri serta memiliki fungsi dan aktivitas wisata yang berbeda. Pantai Barat merupakan pantai yang biasa digunakan oleh wisatawan untuk aktivitas berenang, bermain, berselancar, berperahu, atau sekedar menikmati pemandangan. Pantai Barat terbagi dalam dua zona, yaitu zona berenang dan zona dilarang berenang. Pantai Timur Pangandaran terletak di sebelah timur Kawasan Wisata Pantai Pangandaran dan berbatasan langsung dengan kawasan cagar alam. Pantai Timur diperuntukan untuk aktivitas nelayan dalam mencari ikan dan parkir perahu. Dikarenakan energi gelombang yang relatif tinggi Pantai Timur tidak dapat digunakan untuk aktivitas berenang dan bermain bagi wisatawan. Namun belakangan ini di Pantai Timur terdapat wisata olahraga air seperti banana boat, jetski, donut, dan lain-lain. Pantai Pananjung terletak di kawasan cagar alam dan berdekatan dengan Pantai Barat. Pantai ini dapat dijangkau dengan menggunakan perahu dari Pantai Barat atau berjalan kaki melalui kawasan cagar alam. Daya tarik utama di Pantai Pananjung yaitu pantai ini memiliki pasir berwarna putih, terumbu karang, dan bangkai kapal yang dapat dimanfaatkan sebagai objek berfoto oleh wisatawan.

Periode kunjungan di Kawasan Wisata Pantai Pangandaran dibagi kedalam dua periode yaitu, periode low season dan high season. Periode low season merupakan periode dengan jumlah kunjungan relatif lebih rendah. Periode ini terjadi diluar musim liburan pada bulan Februari - Mei dan Agustus - November. Periode high season merupakan periode dengan jumlah kunjungan relatif lebih tinggi. Periode ini terjadi pada musim libur awal tahun di bulan Januari, musim libur sekolah pada Juni - Juli, dan musim libur akhir tahun pada Desember. Penentuan tingkat risiko wisata akan dibagi berdasarkan kedua periode tersebut untuk melihat perbedaan tingkat risiko wisata pada kedua periode tersebut dengan menggunakan rata-rata jumlah kunjungan harian.
Tabel 2. Kunjungan Wisatawan Pantai Pangandaran Tahun 2019

\begin{tabular}{lc}
\hline \multicolumn{1}{c}{ Bulan } & Jumlah Wisatawan \\
\hline Januari & 81.835 \\
Februari & 67.789 \\
Maret & 79.792 \\
April & 202.757 \\
Mei & 59.491 \\
Juni & 668.062 \\
Juli & 403.853 \\
Agustus & 118.661 \\
September & 162.241 \\
Oktober & 146.295 \\
November & 156.559 \\
Desember & 516.645 \\
Jumlah & 1.990 .776 \\
Kunjungan harian & 4.109 \\
periode low season & \\
Kunjungan harian & 13.654 \\
periode high season & \\
\hline
\end{tabular}

Sumber: Dinas Pariwisata dan Kebudayaan Kab. Pangandaran, 2020

Pantai Pangandaran memiliki kondisi batimetri dengan dasar laut memanjang ke arah laut lepas. Selain itu terdapat pula pola lembah punggungan yang berulang secara teratur. Pantai Pangandaran memiliki dasar pantai dengan pola lembah punggungan lembah yang berulang secara teratur, dengan lembah merupakan celah yang lebih dalam dapat memicu arus rip (Kusmanto dan Setiawan, 2011). Hal serupa diungkapkan oleh Muntasib et al. (2018) dengan pernyataan pantai dengan morfologi beach cup serta morfologi dasar laut yang berupa punggungan dan lembah, merupakan bentuk morfologi yang berpengaruh penting pada pembentukan arus rip karena setelah gelombang pecah, air yang naik ke pantai akan terbelah oleh tanjung (horn) dari morfologi beach cup. Kemunculan arus rip di Pantai Pangandaran semakin memperkuat kesesuaian dari Pantai Pangandaran dengan tipe pantai Longshore bar and trough. Menurut Muntasib et al (2018) kemunculan arus rip di Pantai Pangandaran dapat terjadi hingga 27 kali sehari. Dikarenakan Pantai Pangandaran bertipe Longshore bar and trough, maka diberikan nilai 1,0 untuk tingkat bahaya pantai.

Gelombang pecah $(\mathrm{Hb})$ merupakan gelombang yang merambat dari laut dalam menuju 
pantai dan mengalami perubahan bentuk karena adanya pengaruh perubahan kedalaman laut dan merupakan gelombang terakhir yang terbentuk sebelum sampai ke pantai. Gelombang pecah dipengaruhi oleh kemiringannya, yaitu perbandingan antara tinggi dan panjang gelombang (Zulfadly, 2018).

Berdasarkan data dari Tabel 3 didapatkan rata-rata tinggi gelombang pecah $1,8 \mathrm{~m}$ dan menjadi nilai dari variabel $\mathrm{H}$. Nilai dari variabel $\mathrm{E}$ ditunjukan pada Tabel 4 sedangkan nilai dari variabel W ditunjukan pada Tabel 5. Data tersebut diambil pada dua periode berbeda yaitu, periode low season dan high season untuk membandingkan perbedaan tingkat risiko pada kedua periode tersebut. Pada kedua tabel tersebut terdapat perbedaan nilai antara periode low season dan high season.

Perbedaan nilai (1-E) pada Tabel 4 disebabkan adanya penambahan jumlah lifeguard di Pantai Timur dan Pantai Pananjung pada periode high season sebagai antisipasi lonjakan jumlah pengunjung. Penambahan personil tersebut berasal dari relawan yang telahdibekali pelatihan oleh Balawista sehingga relawan tersebut dapat memberikan pertolongan jika terjadi kecelakaan. Tidak ada penambahan personil lifeguard di Pantai Barat pada periode high season sehingga nilai (1E) pada kedua periode sama.

Hal serupa terjadi pada faktor pencegahan risiko. Pada periode low season jumlah rambu di Pantai Barat hanya berjumlah 3 rambu, sedangkan pada periode high season terjadi penambahan jumlah rambu menjadi 22 rambu. Hal tersebut diakibatkan saat pengamatan pada periode low

Tabel 3. Data gelombang pecah

\begin{tabular}{lc}
\hline \multicolumn{1}{c}{ Bulan } & $\mathrm{Hb}(\mathrm{M})$ \\
\hline Januari & 1,46 \\
Februari & 1,47 \\
Maret & 1,62 \\
April & 1,77 \\
Mei & 1,93 \\
Juni & 2,04 \\
Juli & 2,12 \\
Agustus & 2,15 \\
September & 2,21 \\
Oktober & 1,68 \\
November & 1,76 \\
Desember & 1,55 \\
\hline
\end{tabular}

Sumber: Taofiqurohman et al., 2020 season di bulan November 2019 sedang dilakukan revitalisasi di kawasan Pantai Pangandaran sehingga faktor pencegahan risiko di Pantai Barat pada periode low season hanya bersifat sementara. Walaupun sudah dilakukan revitalisasi tetap tidak ada penambahan rambu peringatan di Pantai Timur dan Pantai Pananjung sehingga faktor pencegahan risiko di Pantai Timur dan Pantai Pananjung tidak bersifat sementara.

Faktor kesiapan keselamatan $(\mathrm{P})$ ditentukan berdasarkan kebijakan yang diterapkan di suatu pantai. Hal tersebut berkaitan dengan pengelola pantai menyediakan lifejacket atau tidak dan apakah pengunjung diwajibkan menggunakannya atau tidak. Semakin tinggi nilai dari $\mathrm{P}$ maka semakin tinggi pula tinggkat risiko dari pantai tersebut. Pantai Barat merupakan pantai yang diperuntukan untuk aktivitas berenang. Namun pengelola pantai tidak menyediakan lifejacket kepada pengunjung yang ingin berenang serta tidak mewajibkan pengunjung untuk membawa dan menggunakan lifejacket saat aktivitas berenang. Dikarenakan pengelola pantai tidak menyediakan dan tidak mengharuskan pengunjung menggunakan lifejacket, maka diberikan nilai $\mathrm{P}$ sebesar1,0 untuk Pantai Barat.

Pengelola pantai di kawasan Pantai Timur tidak menyediakan dan tidak mengharuskan pengunjung menggunakan lifejacket. Namun Pantai Timur merupakan kawasan yang tidak diperuntukan aktivitas berenang sehingga wajar apabila pengelola tidak menyediakan dan tidak mengharuskan pengunjung menggunakan lifejacket. Belakangan ini Pantai Timur dimanfaatkan untuk aktivitas olahraga air. Untuk melakukan aktivitas olahraga air wisatawan diharuskan menggunakan lifejacket yang telah disediakan oleh operator olahraga air sehingga diberikan nilai $\mathrm{P}$ sebesar 0,1 untuk Pantai Timur.

Pantai Pananjung memiliki pemanfaatan sama seperti Pantai Barat, yaitu diperuntukan aktivitas bermain dan berenang. Namun sama seperti Pantai Barat di kawasan ini pengelola tidak menyediakan dan tidak mengharuskan pengunjung untuk menggunakan lifejacket. Dikarenakan hal tersebut maka nilai $\mathrm{P}$ dari Pantai Pananjung adalah 1,0 .

Setelah ditemukan nilai dari tingkat risiko pantai (R), nilai tersebut kemudian dicocokan kedalam matrix assessment risiko pada Tabel 7 . Nilai tingkat risiko (R) dicocokan kedalam matrix untuk selanjutnya ditentukan pada kategori apa pantai tersebut berdasarkan nilai R. Dari hasil 
Tabel 4. Faktor Penyelamatan Darurat

\begin{tabular}{cccccc}
\hline Periode & Pantai & Panjang Pantai (m) & Jumlah Lifeguard & Meter per lifeguard & $(1-\mathrm{E})$ \\
\hline \multirow{3}{*}{ Low Season } & Barat & 2300 & 32 & 72 & 0,07 \\
& Timur & 750 & 1 & 750 & 0,75 \\
& Pananjung & 300 & 1 & 300 & 0,3 \\
\multirow{3}{*}{ High Season } & Barat & 2300 & 32 & 72 & 0,07 \\
& Timur & 750 & 4 & 188 & 0,19 \\
& Pananjung & 300 & 4 & 75 & 0,08 \\
\hline
\end{tabular}

Tabel 5. Faktor Pencegahan Risiko

\begin{tabular}{cccccc}
\hline Periode & Pantai & Panjang Pantai (m) & Jumlah Rambu & Meter per Rambu & $(1-\mathrm{W})$ \\
\hline \multirow{3}{*}{ Low Season } & Barat & 2300 & 3 & 767 & 0,77 \\
& Timur & 750 & 1 & 750 & 0,75 \\
& Pananjung & 300 & 1 & 300 & 0,3 \\
\multirow{3}{*}{ High Season } & Barat & 2300 & 22 & 105 & 0,1 \\
& Timur & 750 & 1 & 750 & 0,75 \\
& Pananjung & 300 & 1 & 300 & 0,3 \\
\hline
\end{tabular}

Tabel 6. Assessment Tingkat Risiko Pantai

\begin{tabular}{ccccccccc}
\hline Periode & Pantai & $\mathrm{S}$ & $\mathrm{N}$ & $1-\mathrm{E}$ & $1-\mathrm{W}$ & $1-\mathrm{P}$ & $\mathrm{H}$ & $\mathrm{R}$ \\
\hline \multirow{3}{*}{ Low Season } & Barat & 1 & 4.109 & 0,07 & 0,77 & 1 & 1,8 & 399 \\
& Timur & 1 & 4.109 & 0,75 & 0,75 & 0,1 & 1,8 & 416 \\
& Pananjung & 1 & 4.109 & 0,3 & 0,3 & 1 & 1,8 & 666 \\
& Barat & 1 & 13.654 & 0,07 & 0,1 & 1 & 1,8 & 172 \\
& Timur & 1 & 13.654 & 0,19 & 0,75 & 0,1 & 1,8 & 350 \\
& Pananjung & 1 & 13.654 & 0,08 & 0,3 & 1 & 1,8 & 590 \\
\hline
\end{tabular}

Tabel 7. Matriks Assessment Risiko

\begin{tabular}{|c|c|c|}
\hline Kategori & $\begin{array}{l}\text { Tingkat risiko } \\
(\mathrm{R})\end{array}$ & Saran Tindak Lanjut \\
\hline $\begin{array}{l}\text { Multiple } \\
\text { fatalities }\end{array}$ & $200+$ & $\begin{array}{l}\text { Tindakan penyelamatan tingkat sangat tinggi harus diterapkan atau tutup } \\
\text { pantai. Menerapkan faktor penyelamatan darurat }\end{array}$ \\
\hline Fatal & $151-200$ & Penyelamatan segera atau tindakan lebih lanjut diperlukan. \\
\hline Critical & $101-150$ & $\begin{array}{l}\text { Tindakan pengendalian dengan tingkatan lebih tinggi harus diterapkan. } \\
\text { Menerapkan faktor pencegahan risiko }\end{array}$ \\
\hline Major & $51-100$ & Diperlukan perhatian. \\
\hline Minor & $1-50$ & $\begin{array}{l}\text { Tindakan pengendalian sudah cukup. Menerapkan faktor kesiapan } \\
\text { keselamatan. }\end{array}$ \\
\hline
\end{tabular}

Sumber: Yang et al., 2014 
tersebut dapat diimplementasikan opsi perlakuan yang diinginkan atau perencanaan aksi untuk mengelola keselamatan pantai. Assessment keselamatan pantai dapat dilihat sebagai nilai kasar risiko dari sebuah pantai. Indeks tersebut berupaya untuk mengidentifikasi risiko yang terasosiasi dengan lingkungan pesisir yang dikaji, bukan bahaya dan risiko spesifik yang terdapat pada lokasi atau kawasan tertentu (Yang et al. 2014).

Hasil perhitungan nilai R (Tabel 6) di ketiga pantai di Kawasan Wisata Pantai Pangandaran umumya memiliki nilai diatas 200 pada kedua periode dan termasuk kedalam kategori multiple fatalities. Kategori tersebut menunjukan bahwa Kawasan Wisata Pantai Pangandaran memiliki tingkat risiko yang tinggi dan diperlukan tindakan penyelamatan lebih lanjut untuk mengatasi bahaya yang terdapat di pantai. Berdasarkan riset Muntasib et al. (2018), potensi bahaya yang sering mengancam wisatawan di Pantai Pangandaran disebabkan oleh faktor fisik yaitu arus rip dan ombak tukik. Arus rip merupakan arus yang bergerak dari arah pantai menuju laut sedangkan ombak tukik merupakan ombak dengan kekuatan yang besar dan curam.

Pantai Barat pada periode high season mengalami penurunan kategori menjadi fatal meskipun pada periode tersebut jumlah kunjungan lebih tinggi. Hal tersebut menunjukan bahwa Pantai Barat relatif lebih aman dikunjungi saat periode high season. Penambahan rambu-rambu peringatan dan penambahan personil lifeguard dapat mengakomodir lonjakan kunjungan wisatawan pada periode tersebut sehingga tingkat risiko pada periode high season lebih rendah dibandingkan dengan periode low season namun dengan jumlah rambu-rambu peringatan dan personil lifeguard lebih sedikit.

Berdasarkan matrix Tabel 7 pantai dengan kategori multiple fatalities terdapat beberapa opsi tindak lanjut berupa penerapan tindakan penyelamatan tingkat tinggi, penerapan faktor penyelamatan darurat, hingga dalam kondisi ekstrim yaitu menutup pantai. Pada Pantai Barat hal utama yang perlu dilakukan yaitu menambah rambu-rambu peringatan mengingat jumlah rambu peringatan terpasang hanya 3 rambu. Menurut Pröbstl-Haider et al. (2016) ketiadaan informasi mengenai risiko membuat pengunjung beranggapan bahwa di kawasan tersebut tidak ada risiko. Jumlah rambu-rambu peringatan yang cukup dan mencakup seluruh kawasan pantai akan memberikan informasi yang lengkap kepada wisatawan, memberikan persepsi bahaya pantai dan menurunkan tingkat risiko pantai. Khusus pada Pantai Timur dan Pantai Pananjung hal yang paling penting untuk dilakukan adalah memasang ramburambu peringatan dan menempatkan pos jaga lifeguard. Pengadaan kedua hal tersebut harus dilakukan terlebih dahulu mengingat di kedua pantai tersebut tidak terdapat rambu-rambu peringatan yang terpasang maupun personil lifeguard yang berjaga di sekitar kawasan pantai tersebut. Setelah kedua hal tersebut terpenuhi maka hal yang selanjutnya dapat dilakukan adalah memberikan edukasi terhadap wisatawan tentang bahaya yang khusus terdapat di salah satu pantai tersebut. Program edukasi harus bertujuan untuk mengenalkan keselamatan di perairan pada usia sedini mungkin melalui serangkaian informasi penting berdasarkan kejadian kecelakaan sebelumnya (ILSE, 2005). Woodward et al. (2015) menyatakan bahwa untuk mendapatkan hasil yang optimal dalam pencegahan bahaya pantai, maka kampanye keselamatan untuk anak-anak dan remaja yang disertai peragaan visual mengenai bahaya pantai merupakan cara komunikasi yang paling efektif. Jika proses edukasi dilaksanakan sebelum sarana dan prasarana terpenuhi maka pencegahan resiko tidak dapat berjalan optimal.

\section{KESIMPULAN}

Kawasan Wisata Pantai Pangandaran termasuk kedalam kategori multiple fatalities dengan nilai $\mathrm{R}$ (tingkat risiko) lebih dari $200 \mathrm{di}$ Pantai Barat, Pantai Timur, dan Pantai Pananjung pada periode low season. Pada periode high season Pantai Barat berubah kategori menjadi fatal dengan nilai 172 , sedangkan pantai lainnya tetap sama. Perbedaan nilai $\mathrm{R}$ menunjukan Kawasan Wisata Pantai Pangandaran relatif lebih aman pada periode high season meskipun jumlah pengunjung jauh lebih tinggi. Hal tersebut dikarenakan jumlah rambu peringatan dan lifeguard lebih memadai pada periode tersebut. Penyebab utama dari tingginya tingkat risiko wisata di Kawasan Wisata Pantai Pangandaran adalah jumlah personil lifeguard dan rambu-rambu peringatan yang tidak mencukupi. Upaya pengoptimalan rambu-rambu peringatan dan meningkatkan pengawasan oleh Balawista khususnya di Pantai Timur dan Pantai Pananjung merupakan langkah efektif yang dapat dilakukan untuk menurunkan tingkat risiko wisata. 


\section{DAFTAR PUSTAKA}

Achjar, K.A. 2020. Keperawatan Wisatawan Pantai untuk Meningkatkan Keselamatan Wisatawan di Tempat Wisata. Jurnal Kesehatan, 11(3): 353-362.

Chris, P. 2014. Coastal Aquatic Risk Assessment. Surf Live Saving Australia, 4-30.

Dinas Pariwisata dan Kebudayaan Kab. Pangandaran. 2019. Laporan Perbandingan Kunjungan Wisata Tahunan. Pangandaran, Jawa Barat.

Hermawan, H. 2017. Kajian Desain Keselamatan Berbasis Lokalitas Dalam Meningkatkan Kepuasan Wisatawan Terhadap Daya Tarik Wisata (Studi Kasus Gunung Api Purba di Desa Wisata Nglanggeran. Jurnal Ilmiah Pariwisata , 22(3):148-162

International Life Saving federation of Europe. 2005. Safety on European Beaches; Operational Guidelines 1st Edition. Germany: ILSE.

Kusmanto, E. \& Setiawan, B.W. 2011. Arus Rip di Teluk Pantai Parigi dan Pantai Pangandaran. Jakarta: Ikatan Sarjana Oseanologi Indonesia (ISOI).

Kusuma, S. \& Suryawan, I. 2016. Penerapan Keselamatan dan Kesehatan Kerja Balawista di Pantai Kuta. Jurnal Destinasi Pariwisata, 4(1):31-35.

Michael, Peter \& Tom, V. 2007. A Guided to Coastal Public Rescue Equipment. Royal National Lifeboat Institution, 10-22.
Muntasib, E., Ulfah, M., Samosir, A. \& Meilani, R. 2018. Potensi Bahaya Bagi Keselamatan Pengunjung di Kawasan Wisata Pantai Pangandaran Kabupaten Pangandaran Jawa Barat. Jurnal Pengelolaan Sumber Daya Alam dan Lingkungan, 8(1):15-25.

Pröbstl-Haider , U., Dabrowska, K. \& Haider, W. 2016. Risk Perception and Preferences of Mountain Tourists in Light of Glacial Retreat and Permafrost Degradation in the Austrian Alps. Journal of Outdoor Recreation and Tourism, 13:66-78.

Short, A. 2006. Australian Beach System-Nature and Distribution. Journal of Coastal Research 22:11-27.

Taofiqurohman, A., \& Ismail, M. 2020. Penilaian Keselamatan Wisata Berdasarkan Parameter Gelombang di Pantai Parigi, Kabupaten Pangandaran Jawa Barat. Jurnal Kelautan Tropis, 23(1):39-46.

Woodward, E., Beaumont, E., Russel, P., \& MacLeod, R. 2015. Public Understanding and Knowledge of Rip Currents and Beach Safety in the UK. International Journal of Aquatic Research and Education, 9(1):49-69.

Yang, B., Lee, J., Hwang, J., Kweon , H., \& Lee, J. (2014). Quantitive Risk Assesment for Beach Drowning Management. Journal of Coastal Research, 117-121.

Zulfadhly. 2018. Kondisi Gelombang Laut dan Transpor Sedimen di Kabupaten Pangandaran. Jatinangor: Fakultas Perikanan dan Ilmu Kelautan Universitas Padjadjaran. 